\title{
Membrane Perturbation by Cerulenin Modulates Glucosyltransferase Secretion and Acetate Uptake by Streptococcus salivarius
}

\author{
By NICHOLAS A. JACQUES \\ Institute of Dental Research, United Dental Hospital of Sydney, Chalmers Street, Surry Hills, \\ N.S.W. 2010, Australia
}

(Received 1 February 1983; revised 13 May 1983)

Cerulenin and dodecanoic acid prevented the synthesis and secretion of glucosyltransferase in non-proliferating cell suspensions of Streptococcus salivarius ATCC 25975 under conditions that also inhibited the incorporation of radioactively labelled acetate into the cell. In the presence of Tween 80 , acetate incorporation was not markedly affected by cerulenin despite the fact that glucosyltransferase secretion was still inhibited. Cerulenin and dodecanoic acid were found to prevent the incorporation of radioactively labelled acetate by affecting the uptake of acetate by the cell. In the case of cerulenin, the inhibition of uptake of acetate by the cell was partially relieved by the addition of Tween 80 . These and other observations strongly suggested that cerulenin inhibited glucosyltransferase secretion and acetate incorporation by perturbing the membrane, rather than by directly inhibiting lipid synthesis.

\section{INTRODUCTION}

The glucosyltransferase(s) of oral streptococci are secreted as a mixture of at least two enzymes which act in a concerted manner in vivo. When separated in vitro these enzymes react with sucrose to synthesize either a soluble glucan with a characteristic branched $\alpha-(1 \rightarrow 6)$ structure or a water-insoluble glucan with a relatively linear $\alpha-(1 \rightarrow 3)$ structure (Hare et al., 1978).

Despite the apparent degree of characterization of the pattern of action of these enzymes, the mechanism of secretion of glucosyltransferase still remains to be elucidated. Growth conditions appear to be important in this process since the amount of glucosyltransferase secreted by oral streptococci varies markedly depending upon the constituents of the growth medium employed (Carlsson \& Elander, 1973; Schachtele et al., 1976; Janda \& Kuramitsu, 1976; Wittenberger et $a l ., 1978$ ) and upon the growth rate and the carbohydrate available to the organism in continuous culture (Carlsson \& Elander, 1973; Hamilton et al., 1979; Hardy et al., 1981). In particular, the enhancement of glucosyltransferase synthesis and secretion by the non-ionic surfactants Emanon 4115 (polyethylene glycol monooleate) and Tween 80 (polyoxyethylene sorbitan monooleate) (Umesaki et al., 1977; Wittenberger et al., 1978) has implicated lipid synthesis in controlling the expression of the enzyme. The antibiotic, cerulenin, has been used to support this view. Cerulenin [(3R)-2,3-epoxy-4-oxo-7,10-dodecadienoyl amide] specifically inhibits the condensation reactions between acyl- and malonyl-thioesters by acting as a non-competitive inhibitor of the enzyme of fatty acid chain elongation (D'Agnolo et al., 1973; Omura, 1976; Vance et al., 1972). The antibiotic also prevents the synthesis and secretion of glucosyltransferase by oral streptococci (Kuramitsu \& Wondrack, 1980; Leung et al., 1980) as well as other extracellular proteins by bacilli (Caufield et al., 1979; Paton et al., 1980).

However, the direct involvement of lipid synthesis in the secretion of glucosyltransferase has to be questioned since other Tween detergents do not promote the secretion of the enzyme in a similar manner to Tween 80 (Wittenberger et al., 1978). Furthermore the interpretation of the mode of action of cerulenin in suppressing secretion by inhibiting lipid synthesis is in doubt 
(Petit-Glatron \& Chambert, 1981). As cerulenin is an amphiphilic molecule it has been argued that it can penetrate and interact with the lipid bilayer. This hypothesis has been supported by studies with dodecanoic acid, a fatty acid with a hydrocarbon backbone the same length as that of cerulenin. Dodecanoic acid has been reported to prevent levansucrase synthesis and secretion in Bacillus subtilis without affecting acetate incorportion into lipids. To account for this and other observations it has been concluded that cerulenin inhibits exoenzyme synthesis and secretion by $B$. subtilis as a result of its physicochemical interaction with the membrane (PetitGlatron \& Chambert, 1981).

In view of these recent findings with cerulenin, the role of the antibiotic in modulating the synthesis and secretion of glucosyltransferase by Streptococcus salivarius has been reappraised. Whereas dodecanoic acid did not directly distinguish between a role for lipid synthesis or a perturbation of the cytoplasmic membrane as a mechanism for modulating exoenzyme secretion in S. salivarius in the same way as reported for B. subtilis (Petit-Glatron \& Chambert, 1981), the use of Tween 80 allowed this distinction to be made.

\section{METHODS}

Organism and medium. Streptococcus salivarius ATCC 25975 was used throughout these studies. Stock cultures were stored at $4{ }^{\circ} \mathrm{C}$ in semi-defined medium containing an excess of $\mathrm{CaCO}_{3}\left(20 \mathrm{mg} \mathrm{ml}^{-1}\right)$. Transfers were made to fresh medium every month. The semi-defined medium was a modification of the strictly defined medium described by Wittenberger $e t$ al. (1978) in which all amino acids except cysteine were replaced with casein hydrolysate $\left(5 \mathrm{~g} \mathrm{l}^{-1}\right)$ (Oxoid) and no further $\mathrm{NaCl}$ was added. The amount of each amino acid in the casein hydrolysate was known from the manufacturer's analysis. Glucose $(25 \mathrm{mM})$ served as the fermentable carbon source.

Chemicals. [U-glucosyl-14 $\mathrm{C}]$ Sucrose, $\left[1,2-{ }^{14} \mathrm{C}\right]$ acetate, $2-\left[\mathrm{G}-{ }^{3} \mathrm{H}\right] \mathrm{deoxy}-\mathrm{D}$-glucose, and the liquid scintillation cocktail Aquasol-2, were purchased from New England Nuclear. Chloramphenicol and cerulenin were purchased from Calbiochem-Behring Australia, Sydney, Australia; dodecanoic (lauric) acid from Ajax Chemicals, Sydney, Australia and Tween $80 \mathrm{from}$ BDH. Stock solutions of cerulenin and dodecanoic acid were prepared in ethanol. As ethanol can perturb the membranes of bacteria (Buttke \& Ingram, 1980; Rigomier et al., 1980) including the membrane of $S$. salivarius (unpublished observations), all traces of ethanol were removed under a stream of nitrogen before use.

Growth measurements. Streptococcus salivarius was grown at $37^{\circ} \mathrm{C}$ in screw-cap bottles containing 50 to $100 \mathrm{ml}$ of the semi-defined medium. Growth was monitored in $14 \mathrm{~mm}$ i.d. test tubes with the aid of a Corning Colorimeter model 252 using a $600 \mathrm{~nm}$ filter (Evans Electroselenium, Halstead, Essex, U.K.). The dry weight of bacteria growing exponentially was linearly related to optical density. An optical density of 1.0 in this system was equivalent to $0.82 \mathrm{mg}$ dry wt cells $\mathrm{ml}^{-1}$.

Non-proliferating cell suspensions. Non-proliferating cell suspensions were used to measure the rate of secretion of glucosyltransferase and acetate incorporation by $S$. salivarius. This was necessary since the use of batch cultures presented a number of problems. For instance, plotting the rate of exoenzyme secretion in the presence of cerulenin either against time or increasing cell number during a period in which the doubling time of the cells altered exaggerated the effects of the antibiotic (cf. Caufield et al., 1979; Kuramitsu \& Wondrack, 1980; Leung $e t$ $a l ., 1980)$. Consequently, by using non-proliferating cell suspensions accurate changes in the rate of exoenzyme secretion with time could be determined.

Cells incubated in non-proliferating suspension medium for 120 min underwent an approximate twofold increase in optical density. The use of mutants unable to synthesize intracellular polysaccharide confirmed that this density change was due to the production of the storage polymer. No measurable increase in cell number was observed when cells present in serial dilutions of the suspension mixture were counted under the microscope (unpublished observations).

The essential requirements for the production of glucosyltransferase in non-proliferating cell suspensions of $S$. salivarius under defined conditions have been referred to previously (Wittenberger \& Wolf, 1979). Cells from $100 \mathrm{ml}$ culture were harvested at mid-exponential phase by centrifugation $\left(8000 \mathrm{~g}, 4^{\circ} \mathrm{C}, 10 \mathrm{~min}\right)$, washed and resuspended to $6 \mathrm{ml}$ in $10 \mathrm{mM}$-potassium phosphate buffer $\mathrm{pH} 6.5$ containing $10 \mathrm{mM}-\mathrm{MgSO}_{4}$. Cells were stored on ice until used (within $10 \mathrm{~min}$ of harvesting) and then equilibrated to $37^{\circ} \mathrm{C}$ for $3 \mathrm{~min}$ prior to addition to preequilibrated suspension medium. Cells were generally resuspended to a concentration of $0.50 \pm 0.1 \mathrm{mg}$ dry wt $\mathrm{ml}^{-1}$ in $5 \mathrm{ml}$ volumes of suspension medium containing $200 \mathrm{mM}$-potassium phosphate buffer (pH 6.5), $7.6 \mathrm{mM}$ $\left(\mathrm{NH}_{4}\right)_{2} \mathrm{SO}_{4}, 0.8 \mathrm{mM}-\mathrm{MgSO}_{4}, 50 \mathrm{mM}$-glucose and hydrolysed casein $\left(5 \mathrm{~g} \mathrm{l}^{-1}\right)$ as a source of amino acids. Although these components were sufficient for the production of glucosyltransferase by non-proliferating cell suspensions, 
sodium acetate was added to a concentration of $200 \mu \mathrm{M}$ in order that all experiments were comparable with those where $\left[{ }^{14} \mathrm{C}\right]$ acetate uptake and/or incorporation were studied. After centrifugation $\left(8000 \mathrm{~g}, 4{ }^{\circ} \mathrm{C}, 10 \mathrm{~min}\right)$, the supernatant was used as the source of secreted enzyme. In order to assay cell-associated glucosyltransferase activity, cells from the non-proliferating cell suspensions obtained by centrifugation were washed and resuspended to $5 \mathrm{ml}$ volumes in phosphate buffer as described above. In order to obtain cell-free extracts these cells were disrupted by sonication (Branson Sonic Power Company, Conn., U.S.A.: Model S75) at $4{ }^{\circ} \mathrm{C}$ and 10 A, $10 \times 30 \mathrm{~s}$ with $30 \mathrm{~s}$ cooling periods, and then reassayed for glucosyltransferase activity. All experiments reported were repeated at least once and all normalized data are accurate within a s.E. of $\pm 3 \%$ of the values shown.

Assay of glucosyltransferase activity. Glucosyltransferase activity was assayed by a modification (Wittenberger $e t$ al., 1978; Jacques \& Wittenberger, 1981) of the procedure described by Robrish et al. (1972). The standard radioactive assay contained $100 \mathrm{~mm}$-potassium phosphate buffer $\mathrm{pH} 6.0,10 \mathrm{mM}-\mathrm{NaF}, 0.1 \mathrm{~mm}$-histidine, $0.5 \mu \mathrm{l}$ Tween $80 \mathrm{ml}^{-1}$, enzyme source $(20$ to $500 \mu \mathrm{l})$ and $10 \mathrm{mM}$-[U-glucosyl- $\left.{ }^{-14} \mathrm{C}\right]$ sucrose $\left(1.39 \mathrm{mCi} \mathrm{mol}^{-1} ; 51.43 \mathrm{MBq} \mathrm{mol}^{-1}\right)$ in a total volume of $2.0 \mathrm{ml}$. The tubes were incubated at $37^{\circ} \mathrm{C}$ for $60 \mathrm{~min}$, after which time the radioactively labelled polysaccharide was precipitated with ethanol, filtered and washed (Jacques \& Wittenberger, 1981). Radioactivity was measured in a Beckman liquid scintillation counter (model LS9000). One unit of enzyme activity (U) was defined as the amount of glucosyltransferase that catalysed the incorporation of $1 \mu \mathrm{mol}$ of the glucose moiety of sucrose into $75 \%(\mathrm{v} / \mathrm{v})$ ethanol-insoluble polysaccharide $\mathrm{min}^{-1}$. In all cases, glucosyltransferase activity was expressed as $U$ (mg dry wt of cells $)^{-1}$, as a means of indicating the amount of enzyme secreted by a given cell mass.

When $S$. salivarius was grown in batch culture in semi-defined medium, the average level of glucosyltransferase produced at stationary phase was threefold greater than the average value of $50 \mathrm{mU}$ (mg dry wt) ${ }^{-1}$ produced by cells grown in the strictly defined medium of Wittenberger et al. (1978). Irrespective of the medium used, the amount of glucosyltransferase produced in non-proliferating cell suspensions after 120 min of incubation was generally twice that produced by the corresponding batch culture. The average levels of glucosyltransferase observed in non-proliferating cell suspensions containing components of the semi-defined medium were therefore about $300 \mathrm{mU}$ (mg dry wt) ${ }^{-1}$.

Acetate incorporation as a measure of lipid synthesis. The rate of lipid synthesis was measured by the rate of incorporation of acetate into TCA-precipitable material (Kuramitsu \& Wondrack, 1980; Leung et al., 1980). Cell suspensions were incubated in the presence of $\left[1,2-{ }^{14} \mathrm{C}\right]$ acetate $\left(200 \mu \mathrm{M} ; 1 \mathrm{Ci} \mathrm{mol}^{-1} ; 37 \mathrm{GBq} \mathrm{mol}^{-1}\right)$. Aliquots $(200 \mu \mathrm{l})$ were taken at the indicated times and added to $200 \mu \mathrm{l}$ volumes of $10 \%(\mathrm{w} / \mathrm{v}) \mathrm{TCA}$ on ice. After all samples had been collected, a $2 \mathrm{ml}$ volume of $10 \% \mathrm{TCA}$ at $4{ }^{\circ} \mathrm{C}$ was added to each tube and the contents filtered through $2.5 \mathrm{~cm}$ Whatman GF/B glass fibre pads under vacuum (Whatman). The sample tubes and filter pads containing the trapped precipitated material were each washed a further three times with $2 \mathrm{ml}$ volumes of $10 \% \mathrm{TCA}$ at $4{ }^{\circ} \mathrm{C}$. After drying at $90^{\circ} \mathrm{C}$ the discs were counted in a liquid scintillation counter as described above.

Uptake of acetate and 2-deoxyglucose by the cell. Transport and incorporation of acetate across the cell membrane of $S$. salivarius was determined by measuring the rate of uptake of $\left[{ }^{14} \mathrm{C}\right]$ acetate over a period of $10 \mathrm{~min}$. At zero time, $\left.100 \mu 110 \mathrm{~mm}-{ }^{14} \mathrm{C}\right]$ acetate $\left(2 \mathrm{Ci} \mathrm{mol}^{-1} ; 74 \mathrm{GBq} \mathrm{mol}^{-1}\right)$ was added to $4.9 \mathrm{ml}$ of a non-proliferating cell suspension and $500 \mu \mathrm{l}$ volumes were removed at $2 \mathrm{~min}$ intervals. The $500 \mu \mathrm{l}$ volumes were filtered under vacuum on $2.5 \mathrm{~cm}$ Whatman GF/B glass fibre discs and washed immediately with six $2 \mathrm{ml}$ volumes of ice-cold $10 \mathrm{mM}$ potassium phosphate buffer $\mathrm{pH} 6.5$ containing $10 \mathrm{mM}-\mathrm{MgSO}_{4}$. This treatment was followed by a further two washes with $2 \mathrm{ml}$ volumes of $75 \%$ ethanol. After completion of drying at $90^{\circ} \mathrm{C}$, the discs were counted in a liquid scintillation counter as described above.

The uptake of 2-deoxyglucose in the presence of glucose was determined in a similar manner to that for the uptake and incorporation of acetate. A non-proliferating cell suspension $(5 \mathrm{ml})$ with or without cerulenin and/or Tween 80 was harvested $\left(8000 \mathrm{~g}, 4^{\circ} \mathrm{C}, 10 \mathrm{~min}\right)$ after $45 \mathrm{~min}$ incubation at $37^{\circ} \mathrm{C}$ and resuspended and equilibrated at $37^{\circ} \mathrm{C}$ in $4.9 \mathrm{ml}$ of an equivalent suspension mixture devoid of glucose. At zero time ( $2 \mathrm{~min}$ after equilibration), $100 \mu 10 \mathrm{~mm}$-glucose containing $4 \mu \mathrm{M}-2-\left[{ }^{3} \mathrm{H}\right]$ deoxyglucose $\left(5000 \mathrm{Ci} \mathrm{mol}^{-1} ; 185 \mathrm{TBq} \mathrm{mol}^{-1}\right)$ was added. Volumes of $500 \mu \mathrm{l}$ were filtered and processed at $1 \mathrm{~min}$ intervals for $5 \mathrm{~min}$ as described above and the rate of uptake of 2deoxyglucose was calculated.

Preparation and analysis of fatty acids. Samples of cells for fatty acid analysis (10 to $50 \mathrm{ml})$ were harvested by centrifugation $\left(10000 \mathrm{~g}, 4^{\circ} \mathrm{C}, 10 \mathrm{~min}\right)$, washed and resuspended in distilled water $(2.5 \mathrm{ml})$. The membrane-bound lipids were extracted according to the method of Bligh \& Dyer (1959), and methyl esters were prepared as reported previously (Jacques, 1982). The fatty acid methyl esters were analysed on a Hewlett-Packard GLC (7600 A Chromatograph System). Samples $(1 \mu \mathrm{l})$ were injected at an initial temperature of $150^{\circ} \mathrm{C}$, the temperature being programmed to rise at $6^{\circ} \mathrm{C} \mathrm{min}-1$ after $1 \mathrm{~min}$ to a final temperature of $240{ }^{\circ} \mathrm{C}$. The column $(2.5 \mathrm{~mm} \times 170 \mathrm{~cm})$ was filled with a commercially prepared packing of $10 \%(w / w)$ SP-2330 on 100/120 Chromosorb (Supelco, Bellefonte, Pa., U.S.A.). Identification of saturated and unsaturated fatty acids was determined by co-chromatography with known standards. The area under each peak was determined in duplicate by the use of a Summagraphics area digitizer (Summagraphics, Fairfield, Conn., U.S.A.). The accuracy of this procedure was confirmed using fatty acid mixtures of known composition. 


\section{RESULTS}

\section{Effect of cerulenin and dodecanoic acid on the synthesis and secretion of glucosyltransferase}

Cerulenin and dodecanoic acid were added in increasing concentrations to non-proliferating cell suspensions. After incubation at $37^{\circ} \mathrm{C}$ for $120 \mathrm{~min}$, the glucosyltransferase activity was measured. Cerulenin $\left(3 \mu \mathrm{g} \mathrm{ml}^{-1}\right)$, inhibited glucosyltransferase synthesis and secretion by $79 \%$, whereas $20 \mu \mathrm{g}$ dodecanoic acid $\mathrm{ml}^{-1}$ was required to obtain a similar degree of inhibition $(83 \%)$ (Table 1). During the course of all incubations, the optical density of the suspensions was monitored at 15 min intervals to determine possible cell lysis. None was apparent.

Neither cerulenin nor dodecanoic acid in the range of concentrations used had any effect on the activity of glucosyltransferase in the in vitro assay system, nor was there any increase in the cell-associated activity or the intracellular activity of disrupted cells after prior incubation for $120 \mathrm{~min}$ in non-proliferating suspension medium. The results indicated that a range of concentrations for cerulenin and dodecanoic acid existed which gave similar inhibitory patterns for the secretion of glucosyltransferase and supported the view that the synthesis of glucosyltransferase in S. salivarius was linked to secretion (Wittenberger et al., 1978).

\section{Effect of Tween 80 on glucosyltransferase secretion}

When cells were incubated in non-proliferating suspension medium for $120 \mathrm{~min}$ with Tween 80 at the relatively low concentration of $0.05 \mu \mathrm{ml}^{-1}$ (Wittenberger et al., 1978), the synthesis and secretion of glucosyltransferase was stimulated. The amount of glucosyltransferase secreted increased from $300 \pm 50 \mathrm{mU}(\mathrm{mg} \text { dry wt) })^{-1}$ in the absence of the detergent, to $650 \pm 50 \mathrm{mU}$ $(\mathrm{mg} \text { dry } w t)^{-1}$ in its presence.

The effect of Tween 80 on modulating the effects of cerulenin and dodecanoic acid on glucosyltransferase secretion was examined. Non-proliferating cell suspensions were incubated for $30 \mathrm{~min}$ in the presence and absence of $2 \mu \mathrm{g}$ cerulenin $\mathrm{ml}^{-1}$. After $30 \mathrm{~min}$, the cell suspension containing the antibiotic was divided into two and $0.05 \mu \mathrm{l}$ Tween $80 \mathrm{ml}^{-1}$ added to one half. All three suspensions were incubated at $37^{\circ} \mathrm{C}$ for a further $90 \mathrm{~min}$. Samples were taken at $15 \mathrm{~min}$ intervals throughout the $120 \mathrm{~min}$ incubation period and chloramphenicol $\left(50 \mu \mathrm{g} \mathrm{ml}^{-1}\right)$ was added to prevent any further synthesis of glucosyltransferase (Wittenberger et al., 1978). Cerulenin at $2 \mu \mathrm{g} \mathrm{ml}^{-1}$ markedly reduced the level of glucosyltransferase secreted during the 120 min incubation. In contrast, cell suspensions containing $2 \mu \mathrm{g}$ cerulenin $\mathrm{ml}^{-1}$ to which $0.05 \mu \mathrm{l}$ Tween $80 \mathrm{ml}^{-1}$ had been added secreted glucosyltransferase at a higher rate. The increased rate of secretion was such that $90 \mathrm{~min}$ after adding the detergent, the amount of glucosyltransferase secreted was the same as in control suspensions devoid of both antibiotic and detergent (Fig. $1 b$ ). Similar results were obtained when $2 \mu$ g cerulenin $\mathrm{ml}^{-1}$ was replaced by $20 \mu \mathrm{g}$ dodecanoic acid ml $\mathrm{m}^{-1}$ (Fig. $1 a$ ), or when cells were harvested, washed and resuspended in fresh medium devoid of cerulenin. The latter result of reversing the inhibitory effects of

Table 1. Effect of cerulenin and dodecanoic acid on synthesis and secretion of glucosyltransferase in non-proliferating cell suspensions

$100 \%$ activity for cerulenin treated cell suspension represented $311 \mathrm{mU}$ (mg dry wt) ${ }^{-1}$ and for dodecanoic acid $295 \mathrm{mU}(\mathrm{mg} \text { dry } \mathrm{wt})^{-1}$. The dry weight of cells in both cases was $0.52 \mathrm{mg} \mathrm{ml}^{-1}$.

\begin{tabular}{|c|c|c|c|}
\hline \multicolumn{2}{|c|}{ Cerulenin } & \multicolumn{2}{|c|}{ Dodecanoic acid } \\
\hline $\begin{array}{l}\text { Concentration } \\
\left(\mu \mathrm{g} \mathrm{ml}^{-1}\right)\end{array}$ & $\begin{array}{c}\text { Glucosyltransferase } \\
\text { activity }(\%)\end{array}$ & $\begin{array}{l}\text { Concentration } \\
\left(\mu \mathrm{g} \mathrm{ml}^{-1}\right)\end{array}$ & $\begin{array}{c}\text { Glucosyltransferase } \\
\text { activity }(\%)\end{array}$ \\
\hline 0.0 & 100 & 0 & 100 \\
\hline 1.0 & 82 & 10 & 85 \\
\hline 2.0 & 43 & 20 & 17 \\
\hline 3.0 & 21 & 30 & 8 \\
\hline $4 \cdot 0$ & 9 & 40 & 3 \\
\hline 5.0 & 7 & 50 & 1 \\
\hline
\end{tabular}




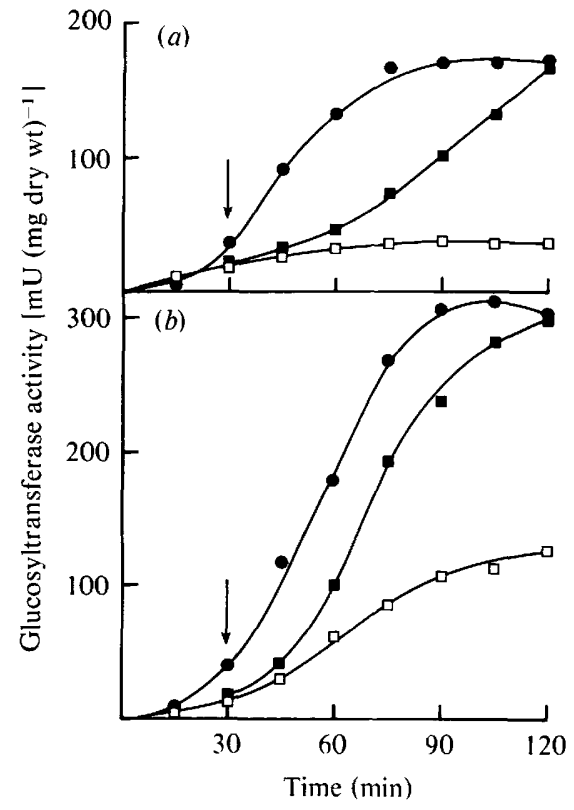

Fig. 1. Effect of Tween 80 on reversing the effect of (a) $20 \mu \mathrm{g}$ dodecanoic acid $\mathrm{ml}^{-1}$ and (b) $2 \mu \mathrm{g}$ cerulenin $\mathrm{ml}^{-1}$ on glucosyltransferase secretion. Samples $(2 \mathrm{ml})$ were removed from $35 \mathrm{ml}$ or $60 \mathrm{ml}$ cell suspensions at the indicated times and cooled on ice in the presence of chloramphenicol $\left(50 \mu \mathrm{g} \mathrm{ml}^{-1}\right)$. After centrifugation, glucosyltransferase activity was assayed. The arrow indicates the point at which the experimental culture was divided into two and $0.05 \mu \mathrm{l}$ Tween $80 \mathrm{ml}^{-1}$ added to one half. $\bigcirc$, No inhibitor; $\square$, inhibitor; $\square$, inhibitor plus $0.05 \mu 1$ Tween $80 \mathrm{ml}^{-1}$.

Table 2. Fatty acid profile of S. salivarius grown in the presence or absence of Tween 80

Cells were grown to mid-exponential phase in the strictly defined medium of Wittenberger et al. (1978) as described in the text. The results are expressed as the percentage of the total fatty acids present in the cell lipids.

Fatty acid

Tetradecanoic $\left(\mathrm{C}_{14: 0}\right)$

Hexadecanoic $\left(\mathrm{C}_{16: 0}\right)$

Hexadecenoic $\left(C_{16: 1}\right)$

Unknown

Octadecanoic $\left(\mathrm{C}_{18: 0}\right)$

Octadecenoic $\left(\mathrm{C}_{18: 1}\right)$

Eicosanoic $\left(\mathrm{C}_{20: 0}\right)$

Eicosenoic $\left(\mathrm{C}_{20: 1}\right)$

Unsaturated/saturated

fatty acid ratio

\begin{tabular}{|c|c|}
\hline \multicolumn{2}{|c|}{ Amount of fatty acid $(\%)$} \\
\hline No Tween 80 & $\begin{array}{c}\text { Tween } 80 \\
\left(0.5 \mu \mathrm{ml}^{-1}\right)\end{array}$ \\
\hline $4 \cdot 6$ & $3 \cdot 5$ \\
\hline 37.7 & $28 \cdot 6$ \\
\hline $10 \cdot 3$ & $11 \cdot 8$ \\
\hline 0.0 & 1.0 \\
\hline 6.3 & 3.8 \\
\hline 31.4 & $42 \cdot 7$ \\
\hline 0.0 & 1.0 \\
\hline $9 \cdot 8$ & $7 \cdot 7$ \\
\hline 1.06 & 1.65 \\
\hline
\end{tabular}

cerulenin by removing the antibiotic has been well established (Kuramitsu \& Wondrack, 1980; Petit-Glatron \& Chambert, 1981).

Fatty acid composition of $S$. salivarius grown in the presence and absence of Tween 80

Cells grown in the absence of Tween 80 were used as a $5 \%(\mathrm{v} / \mathrm{v})$ inoculum for two $100 \mathrm{ml}$ volumes of medium, one of which contained $0.5 \mu \mathrm{l}$ Tween $80 \mathrm{ml}^{-1}$. The fatty acid profile of cells sampled at various stages throughout the growth cycles of both cultures was similar to those given in Table 2 for mid-exponential phase cells. Cells grown in the presence of $0.5 \mu 1$ Tween 80 

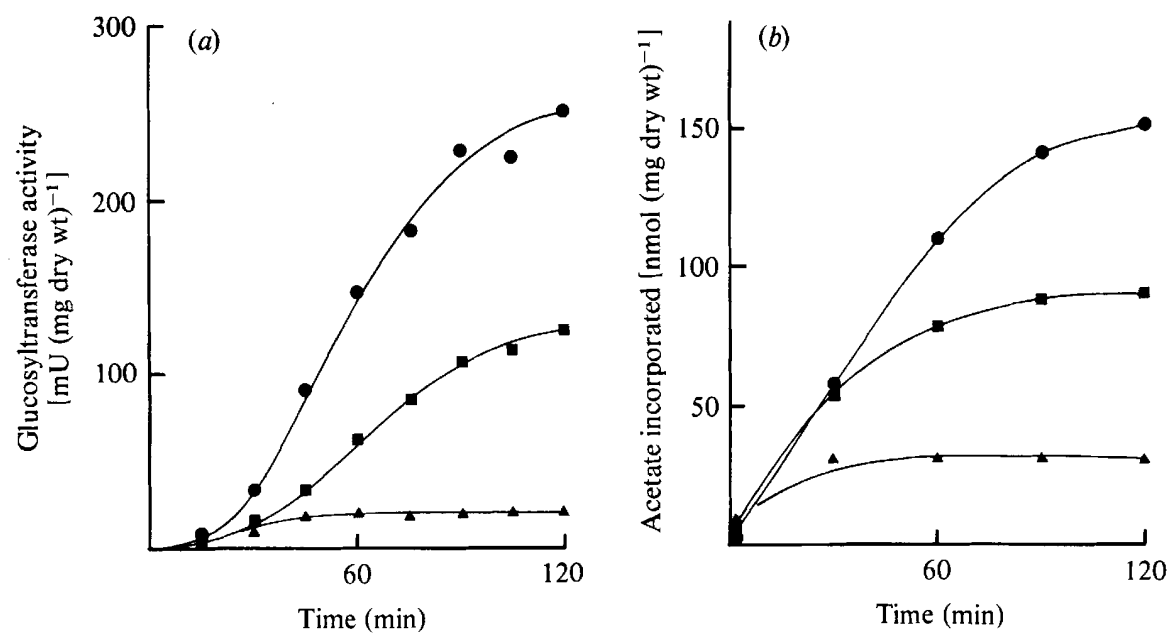

Fig. 2. Effect of cerulenin on (a) glucosyltransferase synthesis and secretion and (b) acetate incorporation. Samples $(2 \mathrm{ml})$ were removed for assay of glucosyltransferase activity as described in Fig. 1. In separate $5 \mathrm{ml}$ cell suspensions containing [ $\left.{ }^{14} \mathrm{C}\right]$ acetate, $200 \mu \mathrm{l}$ samples were taken at the indicated times and mixed with $200 \mu \mathrm{l} \mathrm{TCA}(10 \%)$ on ice. Acetate incorporation was then determined. 0 , Control suspensions, no cerulenin added; $\square$, cerulenin $\left(2 \mu \mathrm{g} \mathrm{m}^{-1}\right) ; \Delta$, cerulenin $\left(5 \mu \mathrm{g} \mathrm{ml}^{-1}\right)$.

$\mathrm{ml}^{-1}$ were enriched with the unsaturated fatty acid, octadecenoic acid, in the membrane lipids, mainly at the expense of the saturated fatty acids hexadecanoic acid and octadecanoic acid. The incorporation of octadecenoic acid resulted in an increase in the unsaturated/saturated fatty acid ratio from $1.06: 1.00$ for cells grown in the absence of Tween 80 to $1.65: 1.00$ for cells grown in its presence (Table 2).

\section{Effect of cerulenin on cells enriched with octadecenoic acid}

Non-proliferating cell suspensions were prepared from bacteria grown in the presence and absence of $0.5 \mu 1$ Tween $80 \mathrm{ml}^{-1}$, and incubated with or without $2 \mu \mathrm{g}$ cerulenin ml-1 for $120 \mathrm{~min}$. Measurement of glucosyltransferase activity indicated that $2 \mu \mathrm{g}$ cerulenin $\mathrm{ml}^{-1}$ caused a $15 \%$ further decrease in secretion of the enzyme in those bacteria pre-grown in the presence of Tween 80 compared with those grown in its absence. The result indicated that an increase in the membrane fatty acid, octadecenoic acid, by prior growth in the presence of Tween 80 did not prevent cerulenin inhibition of the secretion of glucosyltransferase.

\section{Cellular incorporation of acetate in the presence of cerulenin and dodecanoic acid}

The incorporation of radioactively labelled acetate and the secretion of glucosyltransferase in the presence of 0,2 and $5 \mu \mathrm{g}$ cerulenin $\mathrm{ml}^{-1}$ were examined at 15 min intervals. At each concentration of cerulenin the decrease in the amount of acetate incorporated after $120 \mathrm{~min}$ of incubation correlated well with the decrease in the secretion of glucosyltransferase. Furthermore, the time course for the incorporation of acetate possessed similar kinetics to that for glucosyltransferase secretion for each concentration of cerulenin used. For instance, with cerulenin at $5 \mu \mathrm{g} \mathrm{ml}^{-1}$, incorporation of acetate appeared to cease after $30 \mathrm{~min}$. The secretion of glucosyltransferase followed a similar pattern (Fig. 2).

Increasing the concentration of dodecanoic acid also resulted in a decrease in the incorporation of acetate. In the presence of 10, 20,30,40 and $50 \mu \mathrm{g}$ dodecanoic acid ml-1, incorporation of acetate appeared to be linear with time over a $120 \mathrm{~min}$ incubation period (results not shown). This observation differed from that with cerulenin where the amount of acetate incorporated reached a plateau by $120 \mathrm{~min}$. 

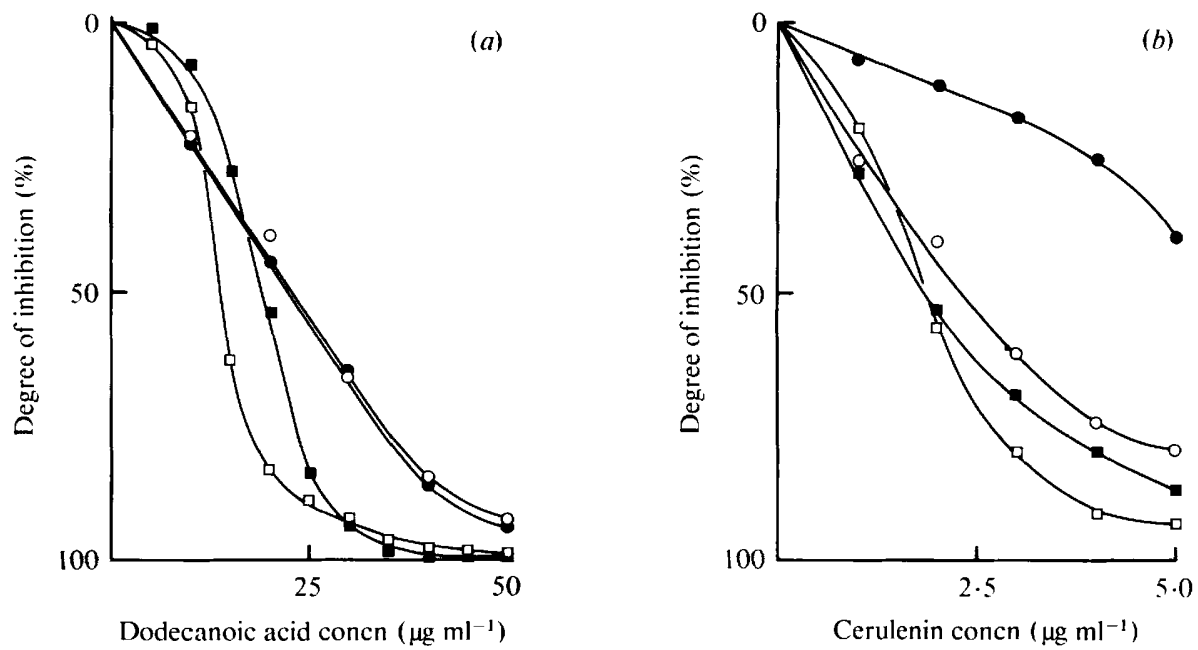

Fig. 3. Degree of inhibition of glucosyltransferase secretion and acetate incorporation by $(a)$ dodecanoic acid and $(b)$ cerulenin in the presence and absence of Tween 80 . Cell suspensions $(5 \mathrm{ml})$ were incubated for $120 \mathrm{~min}$, centrifuged and glucosyltransferase activity determined. Acetate incorporation was measured after $120 \mathrm{~min}$ in similar cell suspensions containing $\left[{ }^{14} \mathrm{C}\right]$ acetate. $\square$, Glucosyltransferase activity (no Tween 80 ); $100 \%$ activity in (a) was $295 \mathrm{mU}$ (mg dry wt) ${ }^{-1}$ and in (b) $304 \mathrm{mU}$ (mg dry wt) ${ }^{-1} ; \square$, glucosyltransferase activity $\left(0.05 \mu \mathrm{l}\right.$ Tween $\left.80 \mathrm{ml}^{-1}\right) ; 100 \%$ activity in (a) was $1179 \mathrm{mU}(\mathrm{mg}$ dry $w t)^{-1}$ and in $(b) 774 \mathrm{mU}(\mathrm{mg} \text { dry wt) })^{-1} ; \mathrm{O}$, acetate incorporated (no Tween 80 ); $100 \%$ incorporation in (a) was $116 \mathrm{nmol}(\mathrm{mg} \mathrm{dry} \mathrm{wt})^{-1}$ and in $(b) 86 \mathrm{nmol}(\mathrm{mg} \mathrm{dry} \mathrm{wt})^{-1}$; incorporated $\left(0.05 \mu \mathrm{l}\right.$ Tween $\left.80 \mathrm{ml}^{-1}\right) ; 100 \%$ incorporation in $(a)$ was $88 \mathrm{nmol}(\mathrm{mg} \mathrm{dry} \mathrm{wt})^{-1}$ and in $(b)$ $85 \mathrm{nmol}$ (mg dry wt) $)^{-1}$.

\section{Effect of Tween 80 on the incorporation of acetate in the presence of cerulenin and dodecanoic acid}

The relationship between acetate incorporation and glucosyltransferase secretion by cell suspensions was studied in the presence of $0.05 \mu l$ Tween $80 \mathrm{ml}^{-1}$. At this concentration, Tween 80 had no significant effect on either the rate or the degree of incorporation of acetate into the cell during a $120 \mathrm{~min}$ incubation period.

As the concentration of dodecanoic acid was increased, acetate incorporation was inhibited to the same extent irrespective of the presence or absence of the detergent (Fig. 3a). Although the pattern of inhibition of glucosyltransferase was similar in the presence of Tween 80 , inhibition was not as pronounced for a given concentration of dodecanoic acid. This gave rise to a shift to the right for the inhibition curve for glucosyltransferase secretion despite the same degree of inhibition of acetate incorporation (Fig. $3 a$ ).

When similar experiments were performed using cerulenin instead of dodecanoic acid, only a minor shift in the inhibition curve for glucosyltransferase synthesis and secretion was observed in the presence of Tween 80 . However, the inhibition of acetate incorporation by cerulenin was significantly reduced in the presence of the detergent (Fig. $3 b$ ). The amount of acetate incorporated in the presence of $2 \mu \mathrm{g}$ cerulenin $\mathrm{ml}^{-1}$ was in fact the same as that in the presence of $5 \mu \mathrm{g}$ cerulenin $\mathrm{ml}^{-1}$ plus $0.05 \mu \mathrm{l}$ Tween $80 \mathrm{ml}^{-1}$.

\section{Uptake of acetate by $S$. salivarius}

The incorporation of radioactively labelled acetate into the lipids of $S$. salivarius is dependent upon two factors. First, the added acetate has to be transported into the cell, and secondly, it has to be incorporated into the lipids. If cerulenin and dodecanoic acid were altering membrane processes directly, then incorporation of radioactively labelled acetate into the cell might be modulated by an effect of these compounds on the transport of acetate by the cell. This possibility was investigated by measuring the rate of uptake of acetate by cell suspensions after 

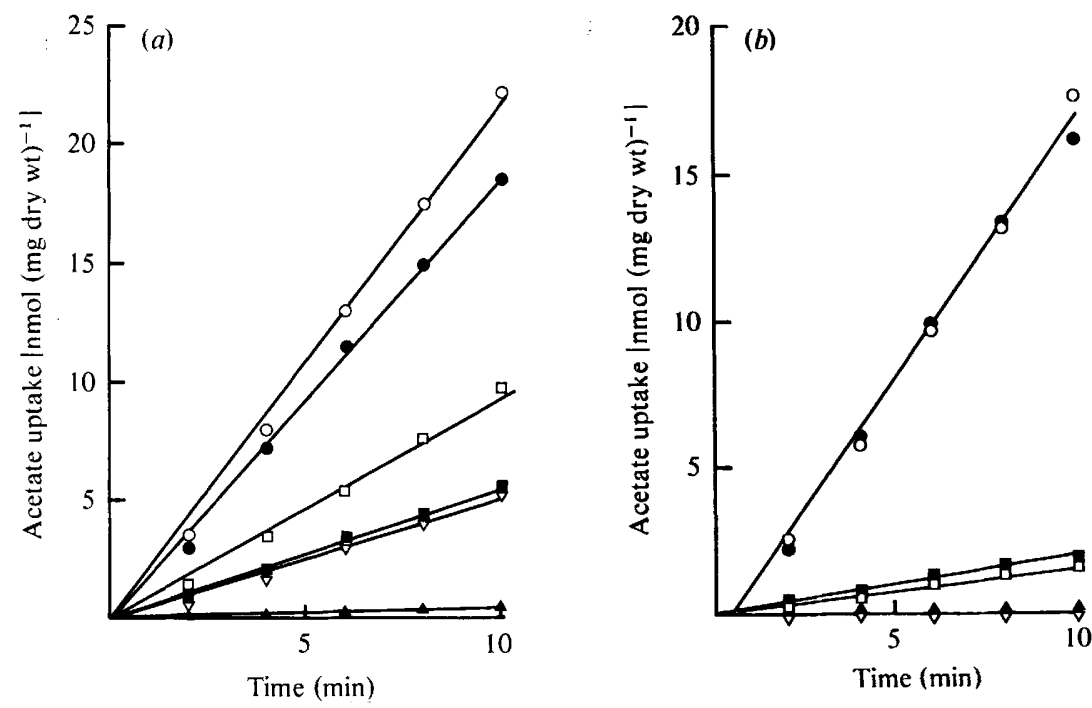

Fig. 4. Effects of $(a)$ cerulenin and $(b)$ dodecanoic acid on the uptake of acetate in the presence or absence of Tween 80 . Cell suspensions $(4.9 \mathrm{ml})$ were incubated in the presence or absence of inhibitor for $40 \mathrm{~min}$ after which time $100 \mu \mathrm{l} 10 \mathrm{~mm}-\left[{ }^{14} \mathrm{C}\right]$ acetate was added. Samples $(500 \mu \mathrm{l})$ were removed at the indicated times, filtered and washed to determine the amount of acetate transported into the cell. Filled symbols, no Tween 80 ; open symbols, $0.05 \mu 1$ Tween $80 \mathrm{ml}^{-1}$. $O$, O, No inhibitor; $\square, \square$, in $(a)$ cerulenin $\left(2 \mu \mathrm{g} \mathrm{ml}^{-1}\right)$ and in $(b)$ dodecanoic acid $\left(20 \mu \mathrm{g} \mathrm{ml}^{-1}\right) ; \Delta, \nabla$, in $(a)$ cerulenin $\left(5 \mu \mathrm{g} \mathrm{ml}^{-1}\right)$ and in (b) dodecanoic acid $\left(50 \mu \mathrm{g} \mathrm{ml}^{-1}\right)$.

an initial $40 \mathrm{~min}$ incubation in the presence of a given concentration of cerulenin or dodecanoic acid. In the presence of 2 or $5 \mu \mathrm{g}$ cerulenin $\mathrm{ml}^{-1}$, the rate of uptake of acetate was reduced by $70 \%$ and $97 \%$, respectively. However, a significant reversal of the inhibition of acetate uptake by the antibiotic was observed when $0.05 \mu \mathrm{l}$ Tween $80 \mathrm{ml}^{-1}$ was added (Fig. $4 a$ ). Interestingly, the rate of uptake of acetate in the presence of $2 \mu \mathrm{g}$ cerulenin $\mathrm{ml}^{-1}$ was the same as that in the presence of $5 \mu \mathrm{g}$ cerulenin $\mathrm{ml}^{-1}$ plus $0.05 \mu \mathrm{l} \mathrm{Tween} 80 \mathrm{ml}^{-1}$ (Fig. $4 a$ ).

Uptake of acetate was also dependent upon the concentration of dodecanoic acid, but independent of the presence or absence of $0.05 \mu 1$ Tween $80 \mathrm{ml}^{-1}$ (Fig. $4 b$ ).

\section{Uptake of 2-deoxyglucose by $S$. salivarius}

Streptococcus salivarius ATCC 25975 possesses two phosphoenolpyruvate :glucose phosphotransferase systems for the uptake of glucose, one of which is specific for the uptake of the nonmetabolizable substrate 2-deoxyglucose (Vadeboncoeur \& Trahan, 1982). It was of interest therefore to determine whether the rate of transport of the non-metabolizable substrate 2-deoxyglucose could also be altered by cerulenin. In the presence of $5 \mu \mathrm{g}$ cerulenin $\mathrm{ml}^{-1}$, the rate of uptake of 2-deoxyglucose was reduced by $48 \%$ compared with control cell suspensions devoid of the antibiotic, where the rate of uptake was equivalent to $187 \mathrm{pmol}(\mathrm{mg} \text { dry wt })^{-1} \mathrm{~h}^{-1}$. Tween 80 $\left(0.05 \mu \mathrm{l} \mathrm{ml}^{-1}\right)$ totally reversed this effect. Interestingly, in the absence of added cerulenin, $0.05 \mu \mathrm{l}$ Tween $80 \mathrm{ml}^{-1}$ increased the rate of uptake of 2-deoxyglucose by $42 \%$ compared with control cultures devoid of the detergent, further indicating that low concentrations of Tween 80 could influence membrane properties.

\section{DISCUSSION}

Cerulenin and dodecanoic acid affected exoenzyme secretion and acetate incorporation by $S$. salivarius in two ways that were significantly different from those reported for $B$. subtilis (Petit- 
Glatron \& Chambert, 1981). First, cerulenin affected secretion at lower concentrations than dodecanoic acid and, secondly, both cerulenin and dodecanoic acid inhibited acetate incorporation throughout the concentration range in which they affected the secretion of glucosyltransferase. Consequently, dodecanoic acid could not be used to distinguish between lipid synthesis or membrane perturbation as the primary site of modulation of exoenzyme secretion in S. salivarius, as was the case with B. subtilis (Petit-Glatron \& Chambert, 1981).

The correlation between cerulenin and dodecanoic acid inhibition of glucosyltransferase secretion and acetate incorporation appeared at first sight to support a role for lipid synthesis in the secretion of glucosyltransferase by oral streptococci (Kuramitsu \& Wondrack, 1980; Leung et al., 1980). However, while there was no known effect of dodecanoic acid as an inhibitor of lipid synthesis, the fatty acid had been reported to modify the phase transition profile of a bilayer of dipalmitoylglycerophosphocholine by penetrating the lipid phase (Jain \& Wu, 1977), as well as to associate reversibly with the cytoplasmic membrane of a Gram-positive organism (Petit-Glatron \& Chambert, 1981).

The non-ionic detergent Tween 80 was found to reverse the inhibitory effect of $2 \mu \mathrm{g}$ cerulenin $\mathrm{ml}^{-1}$ on glucosyltransferase secretion (cf. Fig. 1). If cerulenin were in a state of equilibrium with the cell and its external milieu, Tween 80 might then bind the external antibiotic and so alter its equilibrium with the cell. If this were the case, reversal of the inhibition of the secretion of glucosyltransferase by the detergent could be easily explained in a similar manner to washing cells free of the antibiotic (Kuramitsu \& Wondrack, 1980; Petit-Glatron \& Chambert, 1981; and this paper). However, the degree of inhibition of glucosyltransferase secretion with increasing concentrations of cerulenin was essentially the same whether or not Tween 80 was present (cf. Fig. $3 a$ ), while the absolute amount of glucosyltransferase secreted in the presence of Tween 80 was always two- to threefold greater, irrespective of the concentration of the antibiotic used in this study. The apparent reversal by Tween 80 of the inhibition of glucosyltransferase secretion observed in the presence of $2 \mu \mathrm{g}$ cerulenin $\mathrm{ml}^{-1}$ was therefore due to the stimulatory property of the detergent. This stimulatory effect required the presence of the detergent since the synthesis and secretion of glucosyltransferase was more susceptible to cerulenin in cells enriched with octadecenoic acid by prior growth in the presence of the detergent.

The use of Tween 80, however, enabled a distinction to be made between the role of cerulenin as an inhibitor of lipid synthesis or as a membrane modulating agent. Any apparent correlation between the degree of acetate incorporation into the cell and the inhibition of glucosyltransferase secretion no longer pertained in the presence of $0.05 \mu \mathrm{l}$ Tween $80 \mathrm{ml}^{-1}$. Acetate incorporation, over the range of cerulenin concentrations tested, occurred at elevated rates in the presence of Tween 80, albeit at slightly reduced rates compared with cells suspended in the absence of the antibiotic. These observations suggested that cerulenin could be affecting the transport of acetate across the cell membrane. Studies on the uptake of acetate by the cell supported this view. Of particular interest was the fact that the rate of uptake of acetate in the presence of $2 \mu \mathrm{g}$ cerulenin $\mathrm{ml}^{-1}$ was the same as in the presence of $5 \mu \mathrm{g}$ cerulenin $\mathrm{ml}^{-1}$ plus $0.05 \mu \mathrm{l}$ Tween $80 \mathrm{ml}^{-1}$. This gave rise to an equivalent degree of incorporation of acetate into the cell for these two conditions. Furthermore, cerulenin decreased the rate of uptake of the nonmetabolizable substrate 2-deoxyglucose, whilst the presence of $0.05 \mu 1$ Tween $80 \mathrm{ml}^{-1}$ reversed the effect. The primary role of cerulenin as an inhibitor of glucosyltransferase secretion and acetate incorporation in $S$. salivarius therefore appeared to be due to its ability to perturb membrane structure rather than to inhibit lipid synthesis directly. Such perturbations might influence one or several events required for the initiation of glucosyltransferase secretion, including the direct interaction between polysomes and membranes or the mechanism of translocation of the protein across the cytoplasmic membrane (Smith et al., 1979; Wickner, 1979). Examination of these processes in more detail should enable some of these questions to be answered.

This work was supported by an Australian Post-Doctoral Fellowship awarded by the National Health and Medical Research Council. The fatty acid analyses were performed at the National Institute of Dental Research, Bethesda, Md., U.S.A., while the author was a recipient of a Fogarty International Visiting Fellowship. 


\section{REFERENCES}

BLIGH, E. G. \& DYER, W. J. (1959). A rapid method of total lipid extraction and purification. Canadian Journal of Biochemistry and Physiology 37, 911-917.

ButTKE, T. M. \& INGRAM, L. O. (1980). Ethanolinduced changes in lipid composition of Escherichia coli: inhibition of saturated fatty acid synthesis in vitro. Archives of Biochemistry and Biophysics 203, 565-571.

Carlsson, J. \& Elander, B. (1973). Regulation of dextransucrase formation by Streptococcus sanguis. Caries Research 7, 81-101.

Caufield, M. P., Berkeley, R. C. W., Pepper, E. A. \& Melling, J. (1979). Export of extracellular levansucrase by Bacillus subtilis: inhibition by cerulenin and quinacrine. Journal of Bacteriology 138, 345-351.

D'Agnolo, G., Rosenfeld, I. S., Awaya, J., Omura, S. \& VAGELOS, P. R. (1973). Inhibition of fatty acid synthesis by the antibiotic cerulenin. Biochimica et biophysica acta 326, 155-166.

Hamilton, I. R., Phipps, P. J. \& Ellwood, D. C. (1979). Effect of growth rate and glucose concentration on the biochemical properties of Streptococcus mutans Ingbritt in continuous culture. Infection and Immunity 26, 861-869.

Hardy, L., JacQues, N. A., Forester, H., Campbell, L. K., KNoX, K. W. \& Wicken, A. J. (1981). Effect of fructose and other carbohydrates on the surface properties, lipoteichoic acid production and extracellular proteins of Streptococcus mutans Ingbritt grown in continuous culture. Infection and Immunity 31, 78-87.

HaRe, M. D., Svensson, S. \& Walker, G. J. (1978). Characterization of the extracellular, water-insoluble $\alpha$-D-glucans of oral streptococci by methylation analysis, and by enzymatic synthesis and degradation. Carbohydrate Research 66, 245-264.

JACQUES, N. A. (1982). Relationship between cyclopropane synthetase and the formation of cyclopropane fatty acids by Proteus vulgaris grown under various respiratory conditions. Journal of General Microbiology 128, 177-184.

JACQUES, N. A. \& WITTENBERGER, C. L. (1981). Inactivation of cell-associated fructosyltransferase in Streptococcus salivarius. Journal of Bacteriology 148, 912-918.

JAIN, M. K. \& WU, N. M. (1977). Effect of small molecules on the dipalmitoyllecithin liposomal bilayer. III. Phase transition in lipid bilayer. Journal of Membrane Biology 34, 157-201.

JANDA, W. M. \& KURAMITSU, H. K. (1976). Regulation of extracellular glucosyltransferase production and the relationship between extracellular and cellassociated activities in Streptococcus mutans. Infection and Immunity 14, 191-202.

KuRAMitsu, H. K. \& WondRack, L. (1980). Requirements for fatty acid synthesis and a chelationsensitive step in the production of glucosyltransferase by Streptococcus mutans. Infection and Immunity 27, 107-112.

Leung, W.-L. S., Harlander, S. K. \& Schachtele, C. F. (1980). Streptococcus mutans dextransucrase: effect of cerulenin on lipid synthesis and enzyme production. Infection and Immunity 28, 846-852.

OMURA, S. (1976). The antibiotic cerulenin, a novel tool for biochemistry as an inhibitor of fatty acid synthesis. Bacteriological Reviews 40, 681-697.

Paton, J. C., May, B. K. \& Elliott, W. H. (1980). Cerulenin inhibits production of extracellular proteins but not membrane proteins in Bacillus amyloliquefaciens. Journal of General Microbiology 118, 179-187.

Petit-Glatron, M.-F. \& Chambert, R. (1981). Levansucrase of Bacillus subtilis: conclusive evidence that its production and export are unrelated to fatty acid synthesis but modulated by membranemodifying agents. European Journal of Biochemistry 119, 603-611.

Rigomier, D., BoHIN, J.-P. \& LUBOCHINSKY, B. (1980). Effects of ethanol and methanol on lipid metabolism in Bacillus subtilis. Journal of General Microbiology 121, 139-149.

Robrish, S. A., ReID, W. \& KRICHEVSKy, M. I. (1972). Distribution of enzymes forming polysaccharides from sucrose and the composition of extracellular polysaccharides synthesized by Streptococcus mutans. Applied Microbiology 24, 184-190.

Schachtele, C. F., HaRlander, S. K. \& Germaine, G. R. (1976). Streptococcus mutans dextransucrase: availability of disaggregated enzyme after growth in a chemically defined medium. Infection and Immunity 13, 1522-1524.

Smith, W. P., TaI, P. C. \& Davis, B. D. (1979). Extracellular labelling of growing secreted polypeptide chains in Bacillus subtilis with diazoiodosulfonic acid. Biochemistry 18, 198-202.

UMESAKI, Y., KaWAI, Y. \& MUTAI, M. (1977). Effect of Tween 80 on glucosyltransferase production in Streptococcus mutans. Applied and Environmental Microbiology 34, 115-119.

Vadeboncoeur, C. \& Trahan, L. (1982). Glucose transport in Streptococcus salivarius. Evidence for the presence of a distinct phosphoenolpyruvate :glucose phosphotransferase system which catalyses the phosphorylation of $\alpha$-methyl-glucoside. Canadian Journal of Microbiology 28, 190-199.

VANCE, D., GoldberG, I., Mitsuhashi, O., Bloch, K. OMURA, S. \& NomURA, S. (1972). Inhibition of fatty acid synthetases by the antibiotic cerulenin. Biochemical and Biophysical Research Communications 48, 649-656.

WICKNER, W. (1979). The assembly of proteins into biological membranes: the membrane trigger hypothesis. Annual Review of Biochemistry 48, 23-45.

Wittenberger, C. L. \& Wolf, A. C. (1979). Possible role of fatty acid synthesis in the secretion of glucosyltransferase. Journal of Dental Research 58A, 337.

Wittenberger, C. L., Beaman, A. J. \& Lee, L. N. (1978). Tween 80 effect on glucosyltransferase synthesis by Streptococcus salivarius. Journal of Bacteriology 133, 231-239. 